\title{
Diving in the Digital Disruption Without Losing Oneself: A Study to Define Human Literacy
}

\author{
Y. Bagus Wismanto*, Monika W. Satyajati, Panca Inggit Sari, C.N. Agnes Abadi, Rosi Tri Mukti \\ Faculty of Psychology, Soegijapranata Catholic University, Semarang, Indonesia
}

*Corresponding author: bagusw@unika.ac.id

Article history: Received: 11 January 2020 Received in revised form: 28 June 2020 Accepted: 10 May 2021 Published online: 09 August 2021

\begin{abstract}
To deal with Industry 4.0, college students need to develop not only skills related to computers but also humans. Former Indonesian Minister of Research,Technology, and Higher Education had emphasized the urgency for this area. However, research articles that support the rationale of Human Literacy are still limited. Thus, this research was conducted to find the definition of Human Literacy and its aspects. Interviews were conducted to 41 students from 8 faculties at Soegijapranata Catholic University. This was followed by content analysis to interpret the meaning. We analyzed the compilation of the interview and looped the meaning of Human Literacy for college students into four main points, which are (1) humanizing humans, (2) technology literacy, (3) character formation, and (4) support from significant institutions. Additional quantitative data also showed the needs of discussion about Human Literacy for students. The result accentuates that learning of Human Literacy for future workers is an issue needs to be concerned by Higher Education Institutions.
\end{abstract}

Keywords: college students; future skills; human literacy; technology literacy; character formation.

C2021 Penerbit UTM Press. All rights reserved

\subsection{INTRODUCTION}

The Minister of Research, Technology and Higher Education at the commemoration of the 73rd anniversary of the Republic of Indonesia wrote a speech for the ceremony on August 17, 2018 (Menteri Riset, 2018) His speech pointed out that Indonesia has to struggle to overcome many challenges, namely eradicating corruption, strengthening power competitiveness, and facing the 4.0 industrial revolution. To deal with the 4.0 industrial revolution, the Indonesian people must replace the long-standing literacy that only relies on reading, writing, and mathematics with new literacy in the field of higher education, namely Data literation, Technology Literation, and Human Literation (Noveria \& Hermansah, 2018). These three new literacies need to be mastered by all university graduates in Indonesia. The last literacy is Human Literacy, which is humanitarian, communication and creative design literacy. Furthermore, it was stated that the three new literacies need to be mastered by all college graduates in Indonesia (Menteri Riset, 2018).

Human literation is an interesting idea and needs to be supported by various parties, especially the higher-ups in Central Java. College students in Indonesia have shown several actions related various human issues. One of the significant actions happened in 2019 when college students in various cities united to protest the government on corruption issues that might affect people (Movanita, 2019). Another example on college students' concern on human issues were shown on how they use the technology to enhance quality of life in environmental problems (Lestari, 2019), and use their knowledge to raise the awareness on mental health issues (Arifiani, 2019). These have proved that college students have broad knowledge and involvement in various issues related human. These also proved that they have the capability to improve human literacy.

Searching the key words of human literation through Google-Scholar on August 2018 reported 2.290,000 references related to the word human and literacy separately. None of the references discuss human literation as one variable. The studies related to human literacy have been possibly limited, that it is important to be further investigated. Concerning what The Minister of Research and Technology has conveyed related the importance of human literacy study, college students and lecturers would have a higher responsibility for Human Literacy in Higher Education settings (Menteri Riset, 2018).

According to the dictionary, literacy is a noun that means illiterate, and human as an adjective meaning of people (Echols \& Shadily, 1986). Thus, human literacy refers to the literacy concerning human things. Human literacy is associated and developed with humanity education (Kang, 2017). Human literacy should be possessed by students and lecturers, while humanity education should be provided by lecturers. Therefore, human literacy in this study is understood as humanity literacy that should be possessed by students.

As mentioned before. internet searching has shown no result related to human literacy research. However, experimental research approaching the human literacy variable has been developed by Kang (2017) with the variable of humanity education (Kang, 2017). Kang attempts to provide humanity education and tries to compare the human capacity of the subject before and after treatment/ education. The results show that after the treatment the human capacity of the research subjects is higher than before the treatment. Further, we assume that Human Literacy is related to humanity and also related with the development of technology and educational institution. 
Deeper understanding about Human Literacy is needed in this developing era. Some scientists in the field of psychology believed that technology had stopped the progress of physical and mental evolution (Milam, 2016). Ricciardeli, Nackerud, Quin, Sewll, and Casiano (2020) pointed out that although social media -as one of technological breakthrough helps people connect to each other, it might affect on the quality of empathy. This is the root of humans' ignorance of various issues in this world. Concerns about important issues in the world is something that could affect nationalism and cultural values of Indonesian youth (Saidek, Islami, \& Abdoludin, 2016). Thus, we have concern to create a research to define Human Literacy as a foundation to strengthen more research in this field.

\subsection{LITERATURE REVIEW}

\section{Educational Institution Definition of Human Literacy}

Although no research has defined Human Literacy, two educational institution had in Australia had defined it. First, Edumazing Human Literacy Pedagogy. Edumazing (2017) stated that Human literacy pedagogy has several objectives, including (1) Innovative pedagogy that creates world-class school communities in the future; (2) An environment where teachers and students work together to create exciting lifelong learning opportunities in space that meet individual student needs, generating creativity and innovation in school-community partnerships; (3) School communities that improve relationships and self-efficacy for all stakeholders - students, school staff and parents; (4) A holistic and sustainable model of teaching practice that improves learning outcomes and well-being for all students; (5) Students see and judge themselves as proactive citizens who can make a positive difference and (6) Culture that promotes positive mental health through self-regulation, resilience, and emotional intelligence.

A second educational institution is Maramba Primary School from Victoria-Australia as the Community School of human literacy, Maramba focuses on improving student learning and welfare. Human literacy has a focus on student knowledge about being human and allows students to use this knowledge to empower students' learning and life (Male, 2018). It establishes an important foundation for sustainable learning and prosperity for a lifetime. As a note, creativity is not explicitly mentioned.

Further introduced in the Maramba School that young people face more challenges in their lives now than before, no matter their background and socio-economic status. This century's change in technology and media has enumerated new complexity to the way we relate to other people, our world and ourselves (Male, 2018). This school also support that students who learn Human Literacy would have the ability to help themselves, and this would lead them to healthy and more successful lives.

Human literacy can be understood as the openness of the eyes and heart that focuses on human knowledge as living things and realizes people to concern the knowledge to empower the learning process and life (Male, 2018). Male further states that Human literacy is an essential foundation for going forward and a continuous learning process throughout life and prosperity.

Human literacy goes beyond social and emotional learning. It utilizes the importance of value-based education, improving safety (including Cyber safety), maintaining a growth mindset, and supporting students to become innovative thinkers and actors. Maramba mentioned that human literacy consists of 5 key elements: Social, Physical, Intellectual, Cultural and Emotional (known as S.P.I.C.E. elements).

\section{Educational Concerns on Non-Academical Quality}

Basic and advanced education concerns three human domains, namely cognitive, affective and conative/psychomotor (Sudiardja, Subanar, Sunardi \& Sarkim, 2006). With cognition, humans try to "capture" the nature of the environment and inhabitants/humans through analysis and synthesis of the phenomena. Affective domains for students bring empathy sensitivity and love for others and their environment. Good cognitive and affective development will guide students to behave better. Good behavior is a conative or psychomotor domain.

Education prepares people to take part in community development. The essence of education is inter-subjectivity activities (Sudiardja, Subanar; Sunardi \& Sarkim, 2006). Furthermore, educating someone means helping the person to better understand nature, the connection with each other and the roles and uses for living together. Educated people deserve to uphold human values, describe and socialize them. Value, in this case, is interpreted as something useful, good, and noble so that it is worth trying to be achieved, pursued and owned by someone.

\subsection{METHODOLOGY}

\section{Design}

This research was a mixed qualitative-quantitative study with a grounded theory approach. A part of the research process was quantitative, in which a scale was used to measure Human Literacy tendencies and behaviors. Another part of this research was qualitative using grounded theory to seek general and abstract theories from a process, action or interaction that comes from the views of participants/subjects (Creswell, 2010).

\section{Research Subjects}

The research subjects were students of Soegijapranata Catholic University (SCU) from all faculties, with the following characteristics: (1) Having taken courses in Religion, Civics or Pancasila as these three basic courses involved human literacy contents; (2) Willing to take the time to attend the Focus Group Discussion. Subjects were students from all faculties at SCU as represented in the FGD participants, and the total number of research subjects was 38 people. The subject was invited via a student internet network and came voluntarily. The biggest number of participants ( 8 students) were from the Faculty of Engineering, and the smallest ( 1 student) came from a faculty that had 
the largest number of students, the Faculty of Economics and Business. The subjects involved or participants in the FGD were given reward which are 1 box of snacks, desirable drinks and a block-note with ball-point. The FGD process lasted an average of 2 hours.

\section{Instruments}

For data collection, the main tools were structured interviews and scale methods. The interview method applied interview guides, which were used in Focus group discussions (FGD). In FGD, the discussion material was students' understanding of human literacy. The FGD focused more on the cognitive-understanding dimension from the participants. The questions asked such as: (1) Has the participant ever heard the term Human Literacy; (2) Has the participant ever heard the term literacy (for other purposes); (3) What is the meaning of the term human literacy for participant; (4) Could the participant explain in his/her way about human literacy; (5) Is the term difficult to understand? The data collection is carried out by researchers and several students.

Additional quantitative data were collected using a scale compiled by researchers. Open-ended questions were given to ask about participants' knowledge on the definition, provision, support, and challenges related to Human Literacy. The results of the participants' answers were given a score ranging from 0 to 2 . Zero score were given when participants gave no answer or zero knowledge. Score 1 were given when participants could mention some things that were related to the questions but could not explain further. Score 2 were given for students who could respond the question precisely using elaborative understanding. The were no absolute right or wrong as the answer keys. To do the scoring, the researchers teams use the guidance and discuss each other about the quality of each answer. The minimum total score for this scale was 0 , and the maximum was 8 . This scale was given twice, before and after the participant had a discussion to find out whether the understanding related to the participant's Human Literacy improved better after the discussion.

\section{Research Analysis}

Inductive analysis was intended to develop theoretical reports and general features of topics that would be discussed simultaneously from the field. Issues or stories obtained from the field related to human literacy were analyzed, reflected, and interpreted by researchers. The data obtained would properly construct a theory about human literacy.

The FGD process included (1) introduction and explanation, (2) filling out questionnaire for additional quantitative data, (3) watching short video related to Industry 4.0, statement from the Minister, and the concept of Human Literacy, (4) Focus Group Discussion, and (5) filling the same questionnaire for post-test. Films and slides shown to participants were intended as a stimulus so that the participants caught a picture of life processes, the environment, and technology as a result of human creativity. The first film was a 3 minute 30 seconds long, about the journey of human life telling the history of human travel from childhood to old age and three aspects related to life's journey namely Time, Wealth and Health.

The question raised regarding human literacy was how to respond to the human life process mentioned above. Humans in their life's journey had all three aspects, but not at the same time. Humans put great pressure on themselves. For the sake of being perfect, it must be balanced in getting all three, without being aware of it, not giving happiness and satisfaction in life. When a human got older, all of the time, wealth and health would be taken away.

The second stage of stimulus presented 30 slides about various activities of human life, both positive and negative. The slides had 32 photos and were displayed 5-10 seconds for each slide. The photos showed the scene of Semarang city and outside, and attempted to reflect various aspects of human life.

The second film, 1 minute 58 seconds, was a film that illustrated dialogue and different perspectives between generations, represented by his grandfather and grandchildren. Both the first film and second film were downloaded from the internet which can be downloaded by a certain application. The second film was a film that had no source of reference, so it was quite difficult to trace back.

The whole FGD process proceeded casually, but the discussion process was serious and running well. The entire contents of the conversation were recorded by student assistants. The results of the FGD records and data analysis of the research team could be seen in the appendix.

\subsection{RESULTS}

The analysis process was carried out by the researchers and student assistants. There were three main themes inferred from the whole FGD process, which are (1) humanizing human, (2) technology literacy, and (3) character formation. These themes defined what human literacy according to the participants.

\section{Humanizing Human}

Most of the participants mentioned that human literacy must include the ability to humanize others. Participants expressed their concern related to the social life of people in the digital society, particularly young people. Participants said that people nowadays are more engaged to their gadgets that they forget to care about each other. One participant from the Faculty of Psychology mentioned some real examples.

"[I think that human literacy means] humanizing human. Some people do not realize that they often hurt others. Our generation frequently hurt other without attacking. They hurt others by being ignorant, for instance when they finished eating at McDonald's, they just leave the table without putting their own trash to the garbage. They see the waiter and they always think that the waiter will do the trash, so they do not need to take care of it. I once talked to an office boy and he complained how people of our age seems to forget that office boys are also human."

Some participants defined further about human literacy and the theme of humanizing human. They expressed their concern about the arrogant and egocentric character of people who do not want to pay attention to others. Participants also talked about how people who have 
human literacy should be happy. A participant from the Faculty of Engineering mentioned what he described as a happy person with good human literacy.

"I think people nowadays are only focusing on themselves. They do not like to see others happy. We could see in social media, that people could easily hurt others with comments. And I think human literacy is against it. People [with good human literacy] are happy to share. Their orientation of happiness is not only surrounding themselves. They are capable to feel their own happiness by caring and making others happy."

\section{Technology Literacy}

Although human literacy was defined as humanizing human, some participants also highlighted the need for people to engage with technology. Technology is a part of everyone's life, and although it has some negative sides, there are still a lot of positive sides that needs to be explored. A participant from Faculty of Food Engineering defined that people with a good human literacy should also understand technology regardless of their ages.

"We see generation gap now. Elderly could hardly have a conversation with young generation because they always tell them about the bad sides of technology. They are reluctant to know deeper about technology. [Someone with good human literacy] should not be that way. People need to know the use of technology. People need to still be move along with the development of technology so that they could use it for their daily lives. People should understand that technology brings a lot of positive impact. Elderly should be concerned about the use of technology in health settings because if there was not technology, we might be not as healthy as we are now."

Some other participants also defined that people with good human literacy could use technology wisely. They are aware of the development of technology. People could use it to help them achieve their goals. A participant from the Faculty of Law and Communication mentioned about some advantages of technology.

"There are so many opportunities when we use the technology. Unfortunately, I see a lot of people become the slave of technology that they just use technology to keep them lazy and unmotivated. I could see that people who knows human literacy would also have a good technology literacy, but they use it in a positive way. They could learn English, they could try to be a digital entrepreneur. They could also solve our problems nowadays, for example garbage problems. We could use technology to help us keep the environment clean."

\section{Character Formation}

The other component of human literacy is character formation. Participants highlighted the role of character formation, including in educational settings. They express that a good character is needed to define a person with human literacy. A participant from the Faculty of Languages and Arts suggested that schools should play a role in the character formation.

"People who have human literacy should also have a good character because in this digital era, we learn quickly about a lot of things but sometimes we forgot to look into ourselves and develop ourselves. I read in the internet that some schools abroad pointed out the important role of character formation. Here, in Indonesia, we don't have it. Parents are proud when they have children with advanced knowledge in Maths or IT, but they forgot the character building."

Beside schools, participants also mentioned the role of families. Character formation is seen as an important theme in human literacy, and participants believe that families could make significant impact. A participant from the Faculty of Architecture mentioned the need to include family to enhance human literacy.

"People need to be aware that character starts from parents, from families. I see here in Indonesia, parents are usually busy or only concern about academic performance. Meanwhile, parents from outside our country teach their children to be positive. A kid with good character started from a parent with good parenting. That is why I conclude that people who have good human literacy must also have a good character that was built on their families."

\section{Defining Human Literacy}

From the results, the researcher summarized the definition of Human Literacy from the students of the Faculty of Psychology at SCU that summarize the three components mentioned above. Human literacy is defined as "the process of humanizing humans that involves critical thinking of oneself and others, openness to technology, and the existence of human characters who socially cares each other." In realizing Human Literacy, the involvement of higher institutions, including lecturers, as well as government involvement, was urgently needed.

\section{Additional Quantitative Results}

The questionnaire given by the researcher consisted of two parts consisting of 4 questions. The first part contained a question about the definition of Human Literacy, the subject was asked to mention the definition of Human Literacy that he/she knew. The second part of 3 questions was an understanding of the provisions, support, and challenges faced about the application of Human Literacy in the industrial 4.0 era. All questions were scored and then analyzed. The answer was the subject's opinion. Therefore, the scoring was given on a scale of 0,1 , and 2 . Value of 0 (zero) indicated no answer, or answering not according to instructions. Value of 1 , the subject answered according to instructions but lack of elaborative explanation. A value of 2 was that the subject answered according to the instructions with an elaborative explanation.

The first question was analyzed using the Wilcoxon Signed Rank Test to find out the differences in participants' knowledge before and after the discussion. The data were not normally distributed, so the non-parametric analysis was given. Table 1 shows the 
analysis of Wilcoxon Signed Rank Test. There is a very significant difference in understanding the subject before and after the discussion $(Z=-4,059 ; \operatorname{sig}=0,000)$.

Table 1 Result of wilcoxon signed rank test for human literacy definition for part 1

\begin{tabular}{cc}
\hline Statistic & Results \\
\hline Z & -4.059 \\
\hline Asymp. Sig. (2-tailed) & 0.000 \\
\hline
\end{tabular}

The second part of the question comprised 3 questions supporting knowledge related to Human Literacy. Paired sample t-tests were given to determine differences in participant knowledge about supporting human literacy knowledge. Parametric statistical techniques were used because the data met the normal distribution. The final result is shown in Table 2 . It shows that there is a highly significant difference regarding supporting knowledge related to Human Literacy after participants participate in the discussion $(\mathrm{t}=-4.49, \mathrm{sig}=0,000)$.

Table 2 Result of T-test for human literacy definition for part 1

\begin{tabular}{ccccc}
\hline Mean & Std. Deviation & T & df & Sig \\
\hline-1.09756 & 1.59381 & -4.409 & 40 & 0.000 \\
\hline
\end{tabular}

\subsection{DISCUSSION}

Based on the presentation material of an educative staff from ITS (Surabaya Institute of Technology) about the socialization from government in Industry 4.0 Era (Arifin, 2018), the world of education could not be separated and always related to technological development. What was conveyed by the staff was in line with the second main point of research, which stated that human literacy was related to technology literacy. Technology was always developing and had positive and negative impacts. The development of this technology must not abandon social values. Humans continued to develop and must follow the development of updating technology and improving human literacy.

The government also mentioned that learning process should have the flexibility over time and space, and involve creativity and collaboration (Arifin, 2018). Thus, we suggest that collaboration should be made between students and the universities, in which universities should facilitate the students to enhance their knowledge on human literacy.

Furthermore, the also suggested that learning process moved from andragogy to heutagogy learning processes (Arifin, 2018). Heutagogy is defined as self-determined learning. Heutagogy implemented by applying a holistic approach in developing students' abilities. The learning process in heutagogy was active and proactive of students because students must act as the main agents in their learning, which resulted in personal experience. Educators only act as facilitators of the learning process or provide opportunities for students to make free choices about what will be learned and how to learn it (Blaschke, 2012).

The meaning of heutagogy was in line with the first main idea (1), where Human Literacy was interpreted as a process of humanizing humans, humans must be critical of themselves and their surroundings and therefore needed to be sensitive to people who did not know Human Literacy.

The underlined point is that heutagogy in practice emphasizes the level of independence (higher level of autonomy) and the maturity of students in the learning process (Blaschke, 2012; Arifin, 2018). The level of learning maturity of the learners (the maturity learners) gave an influence on the learning assistance needs, namely the more mature the person in terms of the independent learning, the lower the percentage of learning process control.

The learning maturity was also in line with the main idea of the results of the third study (3) which stated that human Literacy was related to the formation of character or character education so that humans continued to care socially-not individualistically. Most of education institutions in Indonesia understood that character education was essential. Education is more concerned with character development than academic development alone, at least there is a balance between the two (Sahlan \& Prastyo, 2012; Fajarini, 2014). The strong awareness of the importance of character education produces journals that specialize in studies of character education (Sudrajat, 2011).

Character education nowadays is in it vital condition to be strenghtened by teachers, educational institutions, and communities, since it could affect nationalism (Fatoni, 2017). Freeks (2015) also stated that higher education institution should play more roles on developing character building since it has the third largest influence for students after their religion/beliefs and parents. Rokhmand, Syaifudin, and Yuliati (2014) stated that character education should include (1) Strenghtening the academic capability with logic and honesty, (2) Cultivating Nationalism, (3) Cultivating care, tolerance, and respect, (4) Cultivating democratic values, (5) Enforcing law.

However, educating students about character education is not an easy matter. Maccarini (2016) stated that human goods and skills are two different ways that even someone has understood the urge, applying it is a different matter. Randle and Eckerseley (2015) stated that people actually aware and concern about humanity issues, however, this is also correlate with perceived personal stress. Some people, although understand about character education and humanity issues, choose to stay pessimist (Milam, 2016).

The main point of the results of the fourth analysis (4) stated that Human Literacy required the role of the government, the need for the involvement of universities and lecturers. The main point was the core of problems like the speech delivered by the Minister of Research and Technology at the welcoming ceremony on 17 August 2018 in that the future Higher education in Indonesia would have to face the Industrial 4.0 revolution and move from literacy to Data Literacy, Technology Literacy, and Human Literacy.

Complementing the four main ideas that were the result of student discussions, it is important to note that the discourse on Human Literacy was initially new to students. However, the results of quantitative research indicated that students had an increased understanding after attending discussions about Human Literacy. This emphasized the important role of lecturers and higher institutions to 
provide education about Human Literacy because education would bring students to have a deeper understanding and concern about Human Literacy.

Educational systems in some countries had tried to put abstract understanding about values and character in textbook. However, it does not always come to succeed (Arthur, 2016). Thus, a more action is needed, and for college students, it could be started with discussion. Discussions were common activities at the university level, especially to discuss issues or problems in depth. In today's digital era, discussions were often conducted online. However, Chen, Xiang, Sun, Ban, Chen, and Huang (2014) found that on topics that require deeper understanding, students prefer to have face-to-face discussions. The topic of Human Literacy, which was still new and required deep understanding, certainly attracted student discussions.

The discussion was also the first step for students to change their mindsets, learn, and produce outcomes related to the topic of their discussion. Auliah, Anwar, and Hardin (2018) find that students who have followed the discussion show a change in learning outcomes in the context of studying the field of Physics. Annamalai, Manivel, and Palanisamy (2015) find that in medical students, discussions improve their thinking processes and assist their communication process. Therefore, the discussion process in this research was certainly appropriate to help introduce students and provide stimulation to pay attention to Human Literacy. Furthormere after discussion had succeeded, it is also needed to consider another activities, such as intervention camping. Ramiha, Hewson, Little, and Lang (2014) had found that camping could significantly improved positive contact between group and reduced intergroup anxiety. This would help students to practice more on their Human Literacy skills.

\subsection{CONCLUSION}

Based on the above analysis, it can be concluded as follows:

1. Human literacy is understood or interpreted by the participants as human awareness (literacy) of the existence and critical concern of other humans around them. The awareness for other human beings is bothered by the rapid advancement of technology that those who are less sensitive have the possibility of becoming individualistic human beings and abandoning social values.

2. Higher education should prepare students to face the future by providing character education in addition to academic ability. SCU as higher education has organized it, and the results can be seen from this study. Lecturers as facilitators of learning must lead the learning process by mastering the advanced technology and applying it to facilitate the learning process.

3. The process of discussion carried out in this research is a process that provides definitions and concepts of Human Literacy from SCU students. Although this process is classified as a data collection process, on the other hand, the discussion process can also be a step to educate students about Human Literacy. Therefore, discussions and other activities related to Human Literacy certainly need to be held more, especially among students.

\section{References}

Annamalai, N., Manivel, R., \& Palanisamy, R. (2015). Small Group Discussion: Students Perspective. International Journal of Applied and Basic Medical Research, 5(Suppl. 1), S18-S20

Antoni, A. (2018, April 10). Sindonews.com. Retrieved at Agustus 20, 2018 from https://daerah.sindonews.com/read/1296665/203/dinilai-tidak-profesionalmahasiswademo-kpu-jawa-tengah-1523349160/

Arifiani, S. (2019, May 4). BEM UNS ajak mahasiswa peduli kesehatan mental. Harian Solopos. Retrieved from https://www.solopos.com/bem-uns-ajak-mahasiswapeduli-kesehatan-mental-989643 at June 6, 2020.

Arifin, S. (2018, October 29). Innovation Learning in Industry 4.0 Era. Surabaya, Jawa Timur.

Arthur, J. (2016). Convergence on Policy Goals: Character Education in East Asia and England. Journal of International and Comparative Education, 5(2), 59-71. doi: $10.14425 /$ jice.2016.5.2.59

Auliah, A., Anwar, M., \& Hardin. (2018). Enhancing communication capabilities in discussion as an effort to improve learning outcomes: Implementing lesson study in basic chemistry class. Proceedings of the 1st International Conference on Advanced Multidisciplinary Research (ICAMR 2018). https://doi.org/10.2991/icamr-18.2019.16

Blaschke, L. (2012). Heutagogy and Lifelong Learning: A Review of Heutagogical Practice and Self-Determined Learning. The International Review of Research in Open and Distance Learning, 13(1), 56-71.

Blaschke, L., Kenyon, C., \& Hase, S. (2014). Experiences in Self-Determined Learning. South Carolina: CreateSpace.

Chen, P., Xiang, Sun, Y., Ban, Y., Chen, G., \& Huang, R. (2014). Exploring Students; Discussion In Face To Face And Online Synchronous Learning. Emerging Issues in Smart Learning, 183-191. DOI: 10.1007/978-3-662-44188-6_26

Creswell, J. (2010). Research Design: Pendekatan Kualitatif, Kuantitatif dan Mixed. Yogyakarta: Pustaka Pelajar.

Echols, J.M., \& Shadily, H. (1986). Kamus Inggris-Indonesia. Jakarta: Gramedia.

Edumazing. (2017). Why Now is The Time to Become a Human Literacy School Community. Retrieved from http://www.humanliteracy.com.au at August 2018

Fajarini, U. (2014). Peranan Kearifan Lokal dalam Pendidikan Karakter. Sosio Didaktika, 1(2), 123-130.

Fatoni, A. (2017). The Strategy Of Character Education In Globalization Era. International Journal of Scientific \& Technology Research, 6(4), $113-114$.

Freeks, F.E. (2015). The Influence Of Role-Players On The Character-Development And Character-Building Of South African College Students. South African Journal of Education, 35(3), 1-13. Doi: 1015700/saje.v35n3a1086

Kang, K.S (2017). Effect of Humanity Education Program on University Students: Self-esteem, Self-efficacy, and Subjective well-being. Information, 1511-1518.

Lestari, I.P. (2019). Mahasiswa Peduli Lingkungan Dan Mengenal Green Industry. Kompasiana. Retrieved from https://www.kompasiana.com/indripl/5cad5a1fa8bc151f204689c6/mahasiswa-peduli-lingkungan-dan-mengenal-green-industry at June 6, 2020.

Maccarini, A. M. (2016). On Character Education: Self-Formation and Forms of Life in a Morphogenic Society. Italian Journal of Sociology of Education, 8(1), 3155. doi: 10.14658/pupjijse-2016-1-3

Male, T. (2018). Human Literacy. Retrieved from http://www.maramba-ps.vic.edu.au/student-wellbeing/human-literacy/ at 19 September 2019.

Menteri Riset dan Teknologi. (201). Retrieved from https://ristekdikti.go.id/wp-content/uploads/2018/08/Sambutan-Menristekdikti-17-Agustus-2018-final.pdf. Retrieved date: 01 January 2020

Milam, E.L. (2016) The Ascent of Man And The Politics Of Humanity's Future. Endeavor, 40(4), $225-237$.

Movanita, A.N.K. (2019, September 24). Ramai-ramai Ke Jalan, Apa Yang Dituntut Mahasiswa? Kompas Nasional. Retrieved from https://nasional.kompas.com/read/2019/09/24/15440851/ramai-ramai-turun-ke-jalan-apa-yang-dituntut-mahasiswa at June 6, 2020.

Noveria, C.A.P, \& Hermansah. (2018, April 19). Lembaga Pendidikan Kunci Hadapi Industry. Alinea Indonesia. Retrieved from https://www.alinea.id/nasional/lembaga-pendidikan-kunci-hadapi-industri-4-0-b1Ux79bgF at June 6, 2020. 
Ramiha, A.A., Hewstone, M., Little, T.D., \& Lang, K. (2014). The Influence Of Status On The Relationship Between Intergroup Contact, Threat, And Prejudice In The Context Of Nation-Building Intervention In Malaysia. Journal of Conflict Resolution, 58(7), 1202-1229.

Randle, M., \& Eckersley, R. (2015). Public Perceptions Of Future Threats To Humanity And Different Societal Responses: A Cross-National Study. Futures, 72, 4-6.

Ricciardelli, L.A., Nackerud, L, Quinn, A.E., Sewell, M., \& Casiano, B. (2020). Social Media Use, Attitudes, And Knowledge Among Social Work Students: Ethical Implications For The Social Work Profession. Social Sciences \& Humanities Open, 2, 1-9. https://doi.org/10/1016/j.ssaho.2019.100008

Rokhmand, F., Syaifudin, A., \& Yuliati. (2014). Character education for Golden Generation 2045 (National Character Building for Indonesian Golden Years. Procedia - Social and Behavioral Sciences, 141, 1161-1165.

Sahlan, A., \& Prastyo, A.T. (2012). Desain Pembelajaran Berbasis Pendidikan Karakter. Yogyakarta: Ar_Ruzz Media.

Saidek, A.R., Islami, R., \& Abdoludin. (2016). Character Issues: Reality Character Problems And Solution Through Education In Indonesia. Journal of Education and Practice, 7(17), 158-165.

Sudiardja, A., Subanar, G.B., Sunardi, S., \& Sarkim, T. (2006). Karya Lengkap Driyakarya: Esai-esai Filsafat Pemikir yang Terlibat Penuh dalam Perjuangan Bangsanya. Jakara: Gramedia Pustaka Utama.

Sudrajat, A. (2011). Mengapa Pendidikan Karakter? Jurnal Pendidikan Karakter, 1(1), 47-58. 